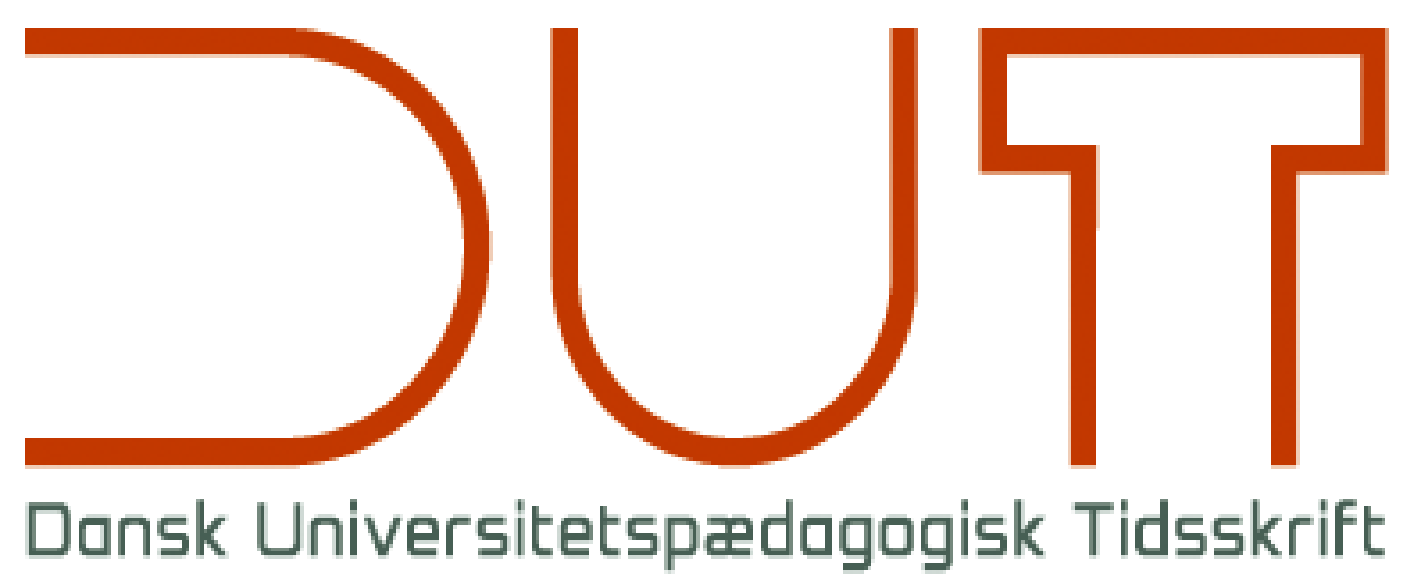

Tema

Undervisningens teknologier og teknikker

Årgang 15 nr. 28 / 2020

Titel

Forfattere

Sidetal

Udgivet af

URL

Betingelser for brug af denne artikel

(c) Copyright
$51-70$

Dansk Universitetspædagogisk Netværk, DUN

> http://dun-net.dk/

Et statistikfags succesfulde omstrukturering - fokus på alignment og god Feedbackpraksis

Morten Nyboe Tabor, Rikke Lyngby von Müllen

Denne artikel er omfattet af ophavsretsloven, og der må citeres fra den. Følgende betingelser skal dog være opfyldt:

- Citatet skal være i overensstemmelse med "god skik"

- Der må kun citeres „i det omfang, som betinges af formålet“

- Ophavsmanden til teksten skal krediteres, og kilden skal angives ift. ovenstående bibliografiske oplysninger.

DUT og artiklens forfatter 


\title{
Et statistikfags succesfulde omstrukturering - fokus på alignment og god feedbackpraksis
}

\author{
Morten Nyboe Tabor ${ }^{a, 1}$, Rikke Lyngby von Müllen ${ }^{\mathrm{b}}$ \\ anstitute for New Economic Thinking \\ bPædagogisk Center Samfundsvidenskab, Københavns Universitet
}

Faglig artikel, fagfællebedømt

\begin{abstract}
Faget Econometrics II blev over en fireårig periode gennemgribende omstruktureret pædagogisk. Motivet var, at for mange studerende lærte for lidt og på for lavt taksonomisk niveau. Omstruktureringens formål var at skabe tydelig alignment mellem fagets læringsaktiviteter, bedømmelse og læringsmål og som en del heraf følge Nicol og Macfarlane-Dick's (2006) syv principper for god feedbackpraksis, der understøtter selvreguleret læring for at hjælpe studerende til en dybere opfyldelse af læringsmålene. For at opnå det introducerede vi en portfolioeksamen baseret på case-opgaver med online peer-feedback og genaflevering, udskiftede traditionelle forelæsninger med et flipped classroom og aktiverede studerende $\mathrm{i}$ øvelsestimerne. Vi beskriver omstruktureringens formål og implementering; analyserer hvorledes implementeringen levede op til de syv principper for god feedbackpraksis; og vi argumenterer for, at omstruktureringen var en stor succes, idet vi efter de nye tiltag har set større arbejdsindsats og læringsudbytte samt højere karakterer og beståelsesrater.
\end{abstract}

\section{Introduktion}

Vi beskriver i denne artikel den omfattende omstrukturering af det obligatoriske bachelorfag Econometrics II på tredje år af økonomistudiet (polit) på Københavns Universitet, som artiklens førsteforfatter gennemførte fra 2015 til $2018 .^{2}$

Motivationen for omstruktureringen var, at for mange studerende leverede en begrænset arbejdsindsats i løbet af semestret og kun opnåede en overfladisk opfyldelse af fagets taksonomisk avancerede læringsmål. En forklaring på dette var, at læringsaktiviteterne, bedømmelsen og læringsmålene ikke i tilstrækkelig grad var alignet med de taksonomisk avancerede læringsmål for faget (Biggs og Tang, 2011), og formålet med omstruktureringen var at skabe en eksamensform og undervisningsaktiviteter, der var alignet med fagets centrale læringsmål på en måde, der kunne hjælpe de studerende til en dybere opfyldelse af læringsmålene.

Vi beskriver i denne artikel motivationen og de teoretiske overvejelser bag omstruktureringen samt den praktiske implementering. Derefter analyserer vi, hvordan den implementere-

\footnotetext{
${ }^{1}$ Kontakt: mortentabor@gmail.com

${ }^{2}$ Førsteforfatteren var drivkraften bag omstruktureringen, men derudover bidrog Adjunkt Rasmus Søndergaard Pedersen (som underviste faget i foråret 2016 og 2017), studielederne Mette Gørtz og Henrik Hansen samt de pædagogiske konsulenter Lotte Sjøsted og Lise Stenbæk til at udvikle fagets nye struktur. Efterfølgende har særligt artiklens andenforfatter bidraget til at videreudvikle undervisningen i faget.
} 
de eksamensform og læringsaktiviteterne byggede på Nicol og MacFarlane-Dick's (2006) syv principper for god feedbackpraksis, der understøtter selvreguleret læring. Endelig argumenterer vi for, at omstruktureringen har været en stor succes, idet vi efter alle de nye tiltag har set en større arbejdsindsats over hele semestret, et større selvrapporteret læringsudbytte samt højere karakterer og en meget lavere dumpeprocent trods en bedømmelse på et højere taksonomisk niveau. Til sidst samler vi op og giver anbefalinger til andre undervisere, der ønsker at lade sig inspirere af eksemplet.

\section{Det pædagogiske problem}

Artiklens førsteforfatter begyndte at undervise Econometrics II i foråret 2015 samtidig med, at han startede på universitetspædagogikum.

Faget udgjorde 7,5 ECTS points og havde i perioden 70-110 og 220-250 studerende i hhv. forårs- og efterårssemestret. Det var inden omstruktureringen bygget op omkring traditionelle forelæsninger suppleret med traditionelle øvelsestimer, hvor studenterinstruktorer gennemgik teoretiske og empiriske opgaver på hold af 30-40 studerende; de studerende skulle have godkendt tre ud af fire mindre empiriske afleveringsopgaver i løbet af semestret for at blive indstillet til eksamen. Eksamen var mundtlig med tyve minutters forberedelse med hjælpemidler. I foråret 2015 var karaktergennemsnittet 4,6 (inkl. reeksamen), og 58 procent af de tilmeldte studerende bestod den ordinære eksamen (67 procent til reeksamen).

For at få flere studerende til at forberede sig til forelæsningerne introduceredes i efteråret 2015 online review-quizzer og online videoer af maksimalt ti minutters varighed. I videoerne anvendte underviser pencasts - hvor der skrives på en tablet-computer, mens underviser forklarer - til at forklare den statistiske teori og screencasts - hvor skærmbilledet optages, mens underviser forklarer - til at vise, hvordan den statistiske software anvendes i praksis. Derudover blev der tilføjet enkelte quizzer med peer-diskussion og student response system i forelæsningerne for at aktivere de studerende. Endelig introduceredes løbende evalueringer med fokus på, hvordan de studerende arbejdede med faget, deres læringsudbytte af fagets forskellige aktiviteter, samt hvordan disse aktiviteter kunne forbedres. Denne løbende evalueringspraksis fortsatte gennem hele forløbet frem til 2018.

Efter disse tiltag steg karaktergennemsnittet til 6,3 i efteråret 2015 (inkl. reeksamen), og 82 procent af de tilmeldte studerende bestod den ordinære eksamen (63 procent til reeksamen).

Trods denne positive udvikling var dumpeprocenten stadig bekymrende, og undervisers indtryk var, at en (for) stor del af de studerende levede op til det meste af Ramsdens (2003, s. 47) beskrivelse af, hvad der karakteriserer en overfladisk læringstilgang. For det første lagde mange studerende en begrænset arbejdsindsats i løbet af semestret. Således svarede kun halvdelen af de studerende i midtvejsevalueringen fra efteråret 2015, at de forberedte sig til forelæsningerne, og i slutevalueringen svarede 34 procent, at de brugte under fire timer ugentligt på faget uden for undervisningstiden. For det andet blev de obligatoriske opgaver typisk kun besvaret på et niveau svarende til, hvad der minimalt krævedes for godkendelse. For det tredje opnåede mange studerende en mangelfuld forståelse af centrale dele af pensum. Eksempelvis afslørede quizzerne i forelæsningerne og den mundtlige eksamen, at mange studerende ikke var i stand til ret meget mere end en mekanisk applikation af matematiske formler uden at kunne overføre dem til en ny kontekst. 
Fagets centrale læringsmål var, at de studerende skulle kunne anvende de statistiske teorier og metoder til at analysere nye data og fortolke og præsentere deres resultater, og lå langt fra den mekaniske applikation, mange studerende præsterede. De mange studerendes overfladiske læringstilgang kunne derfor tyde på, at faget ikke i tilstrækkelig grad var alignet (Biggs og Tang, 2011). Den selvstændige analyse, fortolkning og præsentation var også målet for de obligatoriske opgaver i faget, men disse skulle kun godkendes og indgik ikke i den endelige bedømmelse. Til den mundtlige eksamen skulle de studerende ikke selv analysere nye data og præsentere deres resultater, men gennemgå en statistisk model og fortolke udvalgte resultater af en empirisk analyse foretaget af underviseren. Det forudsigelige resultat var, at de fleste studerende løste de obligatoriske opgaver i løbet af semestret på det minimale niveau krævet for opgavegodkendelse og koncentrerede sig om at lære det, der blev testet til eksamen, frem for det, der var fagets læringsmål.

Denne unalignment gik igen i undervisningsformen, som kun i begrænset omfang aktiverede de studerende eller gav dem løbende feedback på deres opnåelse af læringsmålene. Både forelæsninger og øvelsestimer var fokuserede på transmission af viden fra underviser eller instruktorer til de studerende, og det medvirkede til, at mange studerende lagde en meget begrænset arbejdsindsats i løbet af semestret og i stedet lagde størstedelen af arbejdsindsatsen umiddelbart op til eksamen.

\section{Portfolioeksamen og feedback}

Ved afslutningen af faget i efteråret 2015 stod det klart for førsteforfatteren og hans samarbejdspartnere, at det ikke var nok blot at tilbyde de studerende flere og bedre redskaber til læring: Der var behov for at skabe en klar sammenhæng mellem læringsmål, eksamination og læringsaktiviteter, som kunne hjælpe de studerende til en dybere opfyldelse af læringsmålene. Da faggruppen ikke ønskede at ændre radikalt på læringsmålene, skulle ændringerne i fagets alignment-trekant (Biggs og Tang, 2011) fokuseres på eksamination og læringsaktiviteter.

Der skulle først designes en eksaminationsform, som var bedre alignet med fagets centrale læringsmål, og som i højere grad end tidligere kunne motivere de studerende til løbende at gennemføre læringsaktiviteter og modtage forskellige former for feedback på dem. Gruppen bag faget (se fodnote 1) valgte i efteråret 2016 at udskifte den mundtlige eksamen med en portfolioeksamen, hvor de studerende i løbet af semestret skulle løse case-baserede opgaver, give hinanden online peer-feedback og genaflevere opgaverne til slut (se Tabel 1 for en detaljeret beskrivelse). De case-baserede opgaver skabte alignment mellem bedømmelsen og fagets læringsmål, og den nye eksamensform gjorde det muligt at evaluere bredere og mere overførbare kompetencer på højere taksonomisk niveau og at undgå den tidspressede mundtlige sluteksamens uundgåelige favorisering af studerende med bestemte evner, som ikke nødvendigvis er korreleret med økonometrisk kunnen (Richardson, 2015; Gibbs og Lucas, 1997).

Den nye styrkede sammenhæng mellem læringsmål og bedømmelsesform dannede et solidt fundament for omstruktureringen af læringsaktiviteterne gennem semestret. For at klare sig godt skulle de studerende arbejde selvstændigt og løbende, og læringsaktiviteterne skulle understøtte dem i det. Vi ved fra flere af det sidste årtis metaanalyser af, hvad der påvirker læring, at god feedbackpraksis er en af de væsentligste faktorer, som den enkelte underviser kan påvirke (Hattie, 2009; Schneider og Preckel, 2017), og det var derfor målet at designe undervisningsaktiviteter, hvor de studerende var aktive og løbende fik feedback på deres 
aktivitet og deres progression mod læringsmålene, som de kunne bruge til at tage ansvar for deres egen vej til målene.

Nicol og Macfarlane-Dick (2006) beskriver syv meget anerkendte principper for god feedbackpraksis, der understøtter, at studerende kan selvregulere deres læring. Det var med udgangspunkt i disse principper (se også Nicol et al., 2014), at vi gennemtænkte undervisningen og eksamen med henblik på at skabe den bedst mulige feedbackpraksis.

Man skal dog huske, at forudsætningen for at modtage god feedback er, at man først har produceret noget (Hattie og Timperley, 2007), og det er centralt, at man har gjort sig umage med at producere dette, for at være interesseret i feedback (Draper, 2009; Kluger og DeNisi, 1996). Denne forudsætning er ikke banal, når målgruppen er politstuderende, som er kendt for at være tidsoptimerende og ofte har en stærk præference for at lave mindst muligt studiearbejde i løbet af semestret og så knokle nogle uger op til eksamen. ${ }^{3}$ Portfolioeksamen øgede incitamentet til at bryde denne vane og lære bedst muligt i løbet af semestret, hvilket skabte grundlaget for alle øvrige tiltag for at styrke fagets feedbackpraksis.

Nicol og Macfarlane-Dicks syv principper (2006) siger, at god feedback:

Princip 1: Helps clarify what good performance is.

Princip 2: Facilitates the development of self-assessment (reflection) in learning.

Princip 3: Delivers high quality information to students about their learning.

Princip 4: Encourages teacher and peer dialogue around learning.

Princip 5: Encourages positive motivational beliefs and self-esteem.

Princip 6: Provides opportunities to close the gap between current and desired performance.

Princip 7: Provides information to the teacher that can be used to help shape the teaching.

Det var vores mål at designe fagets læringsaktiviteter, så alle principperne var tænkt ind.

Den overordnede indsats for god feedbackpraksis bestod af tre dele.

Den første var som nævnt at gøre peer-feedback og genaflevering til en integreret del af eksamen, hvilket skulle motivere de studerende til løbende indsats og til at spille en central og aktiv rolle i den løbende feedback.

Den anden var en gradvis udskiftning af traditionelle forelæsninger med et flipped classroom (Bergman og Sams, 2012). Her skulle de studerende selvstændigt opnå læringsmålene ved at forberede sig til forelæsningerne ved 1) at læse en del af pensum, 2) se en online ti-minutters video, hvori underviser gennemgik den relevante del af pensum, 3) besvare en online reviewquiz med multiple-choice spørgsmål og 4) i fagets diskussionsforum stille (anonyme) spørgsmål til pensum eller kommentere, hvilke dele af fagstoffet de ønskede uddybet i den efterfølgende forelæsning.

Som det tredje omstrukturerede vi øvelsestimerne, så de studerende aktivt arbejdede på at løse opgaverne selv, mens underviserne besvarede spørgsmål og gav feedback. I halvdelen af øvelsestimerne arbejdede de studerende med teoretiske opgaver. Her samledes alle stu-

\footnotetext{
${ }^{3}$ l langt størstedelen af BA-fagene er eksamen skriftlig uden hjælpemidler.
} 
derende, underviser og studenterinstruktorer i ét lokale, og de studerende samarbejdede om at løse opgaverne, mens underviserne bevægede sig rundt og gav feedback. Efter timerne var en detaljeret skriftlig løsning på opgaverne tilgængelig. I den anden halvdel af øvelsestimerne, der foregik separat på de enkelte øvelseshold, arbejdede de studerende med at løse empiriske opgaver. De havde adgang til online tutorials, der ved at kombinere videoer, spørgsmål, skriftlige løsninger og quizzer guidede de studerende gennem opgaverne, mens studenterinstruktorerne gav feedback og fulgte op i det omfang, der var behov for det.

Med de syv principper som udgangspunkt vil vi i det følgende belyse detaljeret, hvordan og hvorfor disse tiltag bidrog til en feedbackkultur i faget, som var grundlæggende anderledes end før omstruktureringen.

Vores beskrivelse og analyse trækker ud over forfatternes erfaringer og diskussioner på midtvejsevalueringer og instituttets standardiserede slutevaluering for semestrene fra foråret 2015 til efteråret 2018, en separat evaluering af peer-feedback-processen fra efteråret 2018, interviews med studerende, der tidligere har fulgt faget, og karakterstatistik for faget. Disse datakilder er detaljeret beskrevet i Tabel 2 . 
I løbet af semestret arbejdede de studerende med fem opgaver baseret på relevante cases, eksempelvis baseret på analyser fra Nationalbanken eller publicerede artikler. Opgaverne var åbent formuleret med en kort motivation, et hovedspørgsmål, der skulle besvares, og en databeskrivelse.

For at besvare opgaven skulle de studerende udføre en statistisk analyse og beskrive den anvendte teori og deres resultater i en samlet rapport på maksimalt fem normalsider plus to normalsider til tabeller og grafer. De åbne opgaver kunne besvares på forskellige måder, og der var ikke ét rigtigt resultat, som de studerende skulle nå frem til. I stedet var fokus primært på at motivere og beskrive valg og antagelser, så det stod klart, hvordan man var nået frem til resultaterne og konklusionen.

De studerende måtte aflevere opgaverne i grupper op til tre.

Peer-feedback

Peer-feedback blev givet anonymt og skriftligt via onlineplatformen Peergrade. De fleste studerende afleverede opgaverne i grupper, men de skulle individuelt give feedback på to opgaver. Derfor modtog hver opgave feedback fra ca. fire medstuderende.

Peer-feedbacken var baseret på bedømmelseskriterierne med fokus på, hvad der kunne forbedres i opgaven. Der anvendtes kun skriftlige kommentarer, ikke scores eller karakterer.

De studerende havde mulighed for at kommentere på den feedback, de modtog, og de kunne sætte flag ved feedback, de ønskede, at underviser forholdt sig til.

Eksamensgodkendelse

For at blive eksamensgodkendt skulle hver studerende aflevere minimum fire af de fem opgaver i løbet af semestret og efter aflevering af disse individuelt give peer-feedback på to opgaver (dvs. minimum otte gange peer-feedback).

Eksamen og bedømmelsen

Til eksamen udvalgte underviser tre af de fem opgaver, der var stillet i løbet af semestret, til at indgå i eksamensportfolien og stillede en ny fjerde, teoretisk delopgave, som skulle løses $\mathrm{i}$ eksamensperioden og tilføjes portfolioen. Der var afsat en uge til eksamen, og alle hjælpemidler måtte anvendes. Bedømmelsen tog højde for, at de studerende havde arbejdet med opgaverne over hele semestret.

Tabel 1. Strukturen for de case-baserede opgaver med peer-feedback og portfolioeksamen. 


\begin{tabular}{|c|c|c|c|}
\hline Kilde & Dato & Antal deltagere & Kommentarer \\
\hline $\begin{array}{l}\text { Instituttets standardise- } \\
\text { rede slutevaluering }\end{array}$ & $\begin{array}{l}\text { Forår } 2015 \text { til ef- } \\
\text { terår } 2018 \text {, dog } \\
\text { med undtagelse af } \\
\text { forår } 2016 \text { og } \\
\text { 2017, hvor artik- } \\
\text { lens førsteforfatter } \\
\text { ikke underviste } \\
\text { faget. }\end{array}$ & $\begin{array}{l}\text { Svarprocenter mel- } \\
\text { lem } 15 \text { og } 24 \text { pro- } \\
\text { cent fra foråret } 2015 \\
\text { til efteråret } 2017 . \\
\text { Svarprocenter i for- } \\
\text { året og efteråret } \\
2018 \text { på } 52 \text { og } 63 \\
\text { procent (hhv. } 38 \text { af } \\
73 \text { og } 153 \text { af } 243 \\
\text { tilmeldte studeren- } \\
\text { de), da evaluerin- } \\
\text { gerne blev udfyldt i } \\
\text { forelæsningerne. }\end{array}$ & $\begin{array}{l}\text { Vi fokuserer på spørgs- } \\
\text { målene om de stude- } \\
\text { rendes læringsudbytte } \\
\text { og arbejdsindsats, og vi } \\
\text { citerer enkelte af de } \\
\text { kvalitative skriftlige } \\
\text { kommentarer, som er } \\
\text { typiske for en større } \\
\text { andel besvarelser. }\end{array}$ \\
\hline
\end{tabular}

$\begin{array}{llll}\begin{array}{l}\text { Midtvejsevalueringerne } \\ \text { gennemført af undervi- }\end{array} & \begin{array}{l}\text { Efterår 2015 og } \\ \text { ser selv }\end{array} & \begin{array}{l}\text { Svarprocenter på } 50 \\ \text { og } 75 \text { procent. }\end{array} & \begin{array}{l}\text { Vi inddrager kun svar på } \\ \text { de spørgsmål, der om- } \\ \text { handler de studerendes }\end{array} \\ & & \begin{array}{l}\text { forberedelse til fore- } \\ \text { læsningerne. }\end{array}\end{array}$

Slutevaluering gennem- Efterår 2018. ført af underviser selv

\section{Svarprocent på 50 De studerende blev procent (121 af 243 bedt om at evaluere tilmeldte studeren- deres samlede lærings- de).}

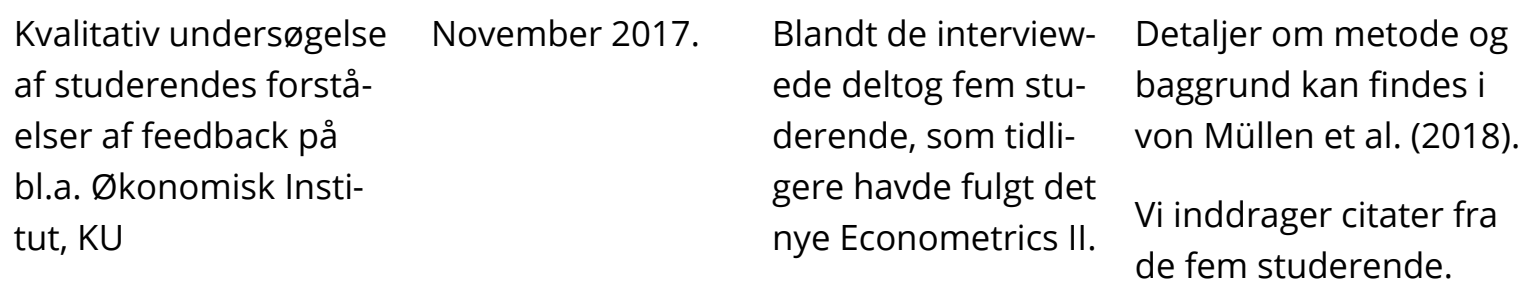




\begin{tabular}{|c|c|c|}
\hline $\begin{array}{l}\text { Karakterstatistik ud- } \\
\text { trukket fra Københavns } \\
\text { Universitets Stads sy- } \\
\text { tem } \\
\text { (http://karakterstatistik. } \\
\text { stads.ku.dk). }\end{array}$ & $\begin{array}{l}2015 \text { til 2018, dog } \\
\text { med undtagelse af } \\
\text { semestrene forår } \\
2016 \text { og forår } \\
2017 \text {, hvor artik- } \\
\text { lens førsteforfatter } \\
\text { ikke underviste } \\
\text { faget. }\end{array}$ & Alle studerende. \\
\hline
\end{tabular}

Tabel 2. Tabellen beskriver analysens datakilder.

\section{God feedbackpraksis}

En stor, synlig og ikke mindst tvungen del af feedbacken i faget var den peer-feedback, de studerende skulle give på hinandens opgaver. Det er særligt vigtigt, når man gør en læringsaktivitet obligatorisk, at den bliver så udbytterig som muligt for så mange som muligt; og målet om velfungerende peer-feedback har stået centralt i bestræbelserne på at udvikle faget. Vi beskriver derfor først, hvordan implementering af peer-feedback på opgaverne fulgte de syv principper. Derefter beskriver vi, hvordan læringsaktiviteterne i forbindelse med undervisningen fulgte de syv principper.

\section{Feedback på obligatoriske opgaver}

Det første princip om, at det skal gøres klart, hvad er en god præstation er, er særligt centralt i peer-feedback, og der blev fra starten lagt stor vægt på at synliggøre bedømmelseskriterierne ved at præsentere og diskutere dem i undervisningen. De nedskrevne kriterier for de studerendes peer-feedback-givning, som blev formuleret som spørgsmål i den online platform, de udvekslede feedback igennem (Peergrade), fokuserede på, hvordan en konkret opgave kunne forbedres med udgangspunkt i bedømmelseskriterierne.

Figur 1 viser, at 73 procent af de studerende vurderede at have opnået et stort eller meget stort læringsudbytte af at læse bedømmelseskriterierne. En studerende udtrykte det på følgende måde:

Reading the assessment criteria has definitely also been giving, as it becomes clear what actually should be included and what you are being assessed on (it's more specific than the general assessment paper on Absalon.

(Evaluering af peer-feedback, efterår 2018)

Gennem løbende feedback og inddragelse af de studerende blev kriteriernes præcision og transparens forbedret hvert semester. 


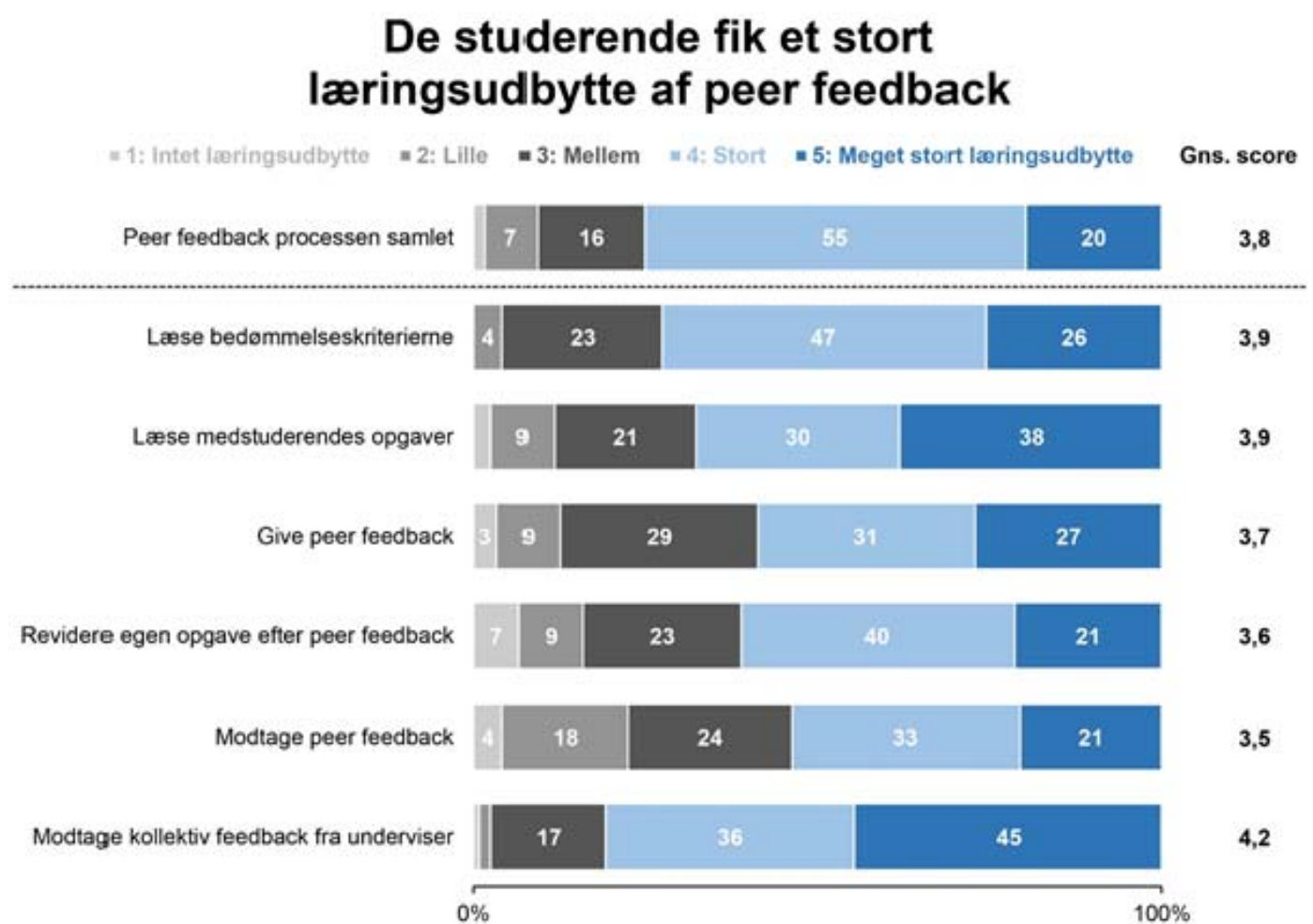

Figur 1. Figuren viser de studerendes selvrapporterede læringsudbytte af peer-feedbackens delkomponenter og samlet set på baggrund af evaluering af peer-feedback foretaget i december 2018.

Nicol og Macfarlane-Dick (2006) nævner det velkendte fænomen, at det er vanskeligt at skabe overensstemmelse mellem fagfeltets og de studerendes forståelser af opgavekriterier alene gennem kriterier, som altid vil udgøre en forsimpling. Den måske mest effektive vej til task representation eller genreforståelse går igennem exemplars; at se (gerne velfungerende) varierende eksempler på genren er en genvej til en nuanceret forståelse af kriterierne (Rienecker og Jørgensen, 1999, s. 55-62). De studerende fik gennem peer-feedbacken over hele semestret adgang til mindst otte ret varierede eksempler på den slags tekster, de også selv skulle producere.

Mange studerende rapporterer selv, at de fik et stort udbytte af at få adgang til andre studerendes eksempler (von Müllen et al. (2018); Deiglmayr, 2018), og de studerende i Econometrics II var ingen undtagelse, som det ses af Figur 1 og følgende citater:

It was a great inspiration to see others' assignments, to see different ways of doing it.

Virkelig god måde at arbejde med ens afleveringer på. Normalt ville man bare smide opgaven vaek, efter den blev godkendt, men når man nu tvinges til at rette de andres, bliver man meget mere opmaerksom på, hvordan en god opgave skal skrives.

(Evaluering af peer-feedback, efterår 2018)

Endelig bidrog underviser også til uddybning af kriterier med mini-examplars ved efter hver runde peer-feedback at give kollektiv feedback i en forelæsning på, hvad der kunne forbedres i opgaverne. Til forelæsningen uddelte underviser specifikke afsnit fra opgaver til de studerende. Afsnittene var udvalgt repræsentativt på baggrund af undervisers erfaring fra tidli- 
gere semestre og det tilfældige udvalg af opgaverne, underviser altid læste. Først gennemgik underviser kort kriterierne for den gode opgave, hvorefter de studerende læste og diskuterede de uddelte afsnit. Efterfølgende gennemgik underviser kollektivt sin feedback på afsnittene. Derigennem anvendtes konkrete eksempler til at illustrere, repetere og tydeliggøre, hvad kriterierne for den gode præstation var. Også denne indsats for kriterieafklaring oplevede de studerende at lære meget af, som det kan ses i Figur 1; og selvom det ikke var deres egen opgave, satte undervisers eksemplificerede feedback dem i gang med selvevaluering og -refleksion, som er Nicol og Macfarlane-Dicks andet princip.

Det er peer-feedbacks største styrke, at de studerende ved at give feedback kvalificeres til at se deres eget produkt med et mere kritisk blik (Nicol et al., 2014; Reinholz, 2016, s. 306), hvilket mange studerende beskriver:

Jeg synes, jeg loerte ret meget af det på den måde, at jeg ikke bare laeste en opgave og tæenkte 'Så har jeg loest en opgave'; jeg blev nødt til at reflektere over, om det rent faktisk gav mening. Så en meget mere kritisk tilgang til det, jeg nu sad og loeste, som jeg helt klart føler, at jeg har kunnet tage med mig, når vi sidder og loeser videnskabelige artikler. Bare fordi der er en eller anden professor ovre i USA, der har skrevet det, behøver det ikke at give mening.

(von Müllen et al. (2018), s. 98)

It made you think about the assignments in a more critical way.

The learning outcome was significant higher since the peer feedback required us to look at the assignment from different angles.

To me peer feedback was great in terms of reflecting over both the assignments which I gave feedback to, but also over my own assignments because it gave me other perspective to how the given assignment could be solved.

(Evaluering af peer-feedback, efterår 2018)

Det sidste citat peger meget specifikt på, hvordan det at give peer-feedback også via sammenlignende selvevaluering kunne føre til forbedringer af eget produkt, som f.eks. Nicol et. al. (2014) også påpeger.

Generelt giver studerende ofte udtryk for, at deres medstuderende ikke er kvalificerede til at give dem feedback, hvilket en mindre gruppe studerende også gav udtryk for i Econometrics II. Det kan naturligvis udgøre et brud med det tredje princip om, at god feedback skal levere kvalitetsinformation til de studerende. Men det kan også være selve kilden til læring, at man er nødt til at forholde sig kritisk til den feedback, man modtager (Nicol et al., 2014; Gibbs, 1999), og netop den mistillid til feedbackgiver betød, at de studerende også ved modtagelsen af feedback blev tvunget til kritisk stillingtagen. De vidste, at ikke alt, hvad deres medstuderende skrev, var rigtigt, og de måtte derfor selv foretage en sortering.

Der har jeg fået feedback fra de der andre studerende, og så er halvdelen af det ubrugeligt, men halvdelen af det kan bruges til noget (...)

(von Müllen et al. (2018), s. 89)

Når den studerende her fortæller, at halvdelen af peer-feedbacken var ubrugelig, men den anden halvdel var nyttig, har han antageligvis læst og vurderet det hele grundigt. Derigen- 
nem blev den studerende involveret $\mathrm{i}$ en akademisk stillingtagen på et højt taksonomisk niveau, som vi som uddannelsesplanlæggere gerne ser vores studerende træne (von Müllen et al. (2018), s. 94-95).

Det er selvfølgelig stadig diskutabelt, om peer-feedback er den bedste måde at efterleve det tredje princip om at give de studerende kvalitetsinformation om deres læring. Der var dog nogle studerende, der argumenterede for, at medstuderende gav bedre feedback end undervisere, fordi medstuderende bedre kunne sætte sig ind i andre studerendes faglige tankegang og misforståelser, end underviser kunne.

De [medstuderende] kan måske i højere grad sige 'Jeg kan se, at du har skrevet det på den her måde; jeg kan godt forstå, at du har forstået det på denne måde, fordi det kunne jeg også, fordi jeg er på samme niveau, men jeg tror, den rigtige måde i stedet for er det her'. Man har måske nemmere ved at saette sig ind i hinandens tankegang på den måde. End en underviser eksempelvis ville.

(Citat fra interview, von Müllen et al. (2018), s. 88)

Endelig så vi flere studerende tale om i interviews, hvordan underviser tog fat i de studerende, der havde brugt alt for lidt tid på at lave peer-feedbacken, og krævede, at de lavede det om, og dermed bidrog til en vis standard for indsatsen.

(...) han går altid op til foreloesningen, første forelaesning, og siger: Og til jer 26, der loggede ind på Peergrade et kvarter før deadline for at rette dem og rettede tre afleveringer på et kvarter i alt, jeg kan fortcelle jeg, at jeg nu har genåbnet jeres Peergrade-system, så I har en dag mere. Hvis I ikke gør det der, så kommer I ikke til eksamen. Jeg gider ikke det der, I skal ikke bruge et kvarter på at rette tre afleveringer.

(Citat fra interview, von Müllen et al. (2018), s. 83)

Der er altså flere forskellige grunde til, at vi mener, at den samlede pulje af peer-feedback havde en rimelig kvalitet, selvom det utvivlsomt var muligt at finde enkeltbidrag, der ikke i sig selv levede op til det tredje princip.

Hvad angår det fjerde princip udgjorde peer-feedbacken i sig selv en slags peer dialogue around learning. Feedbackplatformen understøttede desuden flere muligheder for dialog mellem feedback-modtageren, feedback-giveren og underviser, idet de studerende blev bedt om at rate kvaliteten af den feedback, de modtog, og de havde muligheden for at kommentere på den modtagne feedback og derigennem indgå i dialog med feedback-giver. Yderligere kunne de sætte flag ved modtagerfeedback, som de havde behov for, at underviser forholdt sig til (hvilket også mindskede risikoen for at efterlade de studerende med feedback af dårlig kvalitet jf. tredje princip).

Derudover lavede langt størstedelen af de studerende opgaverne sammen med en eller to medstuderende, hvilket faciliterede dialog om de studerendes læring internt i grupperne. Det skete dels i forbindelse med, at grupperne lavede opgaverne, men også når grupperne konfererede om, hvilke af peer-feedbackens ændringsforslag, de skulle implementere inden genaflevering. Dermed foregik der i praksis mere peer dialogue around learning, end man måske ville antage blev resultatet af den anonyme envejskommunikation, som peerfeedbacken faciliterede. 
Under det femte princip om, at feedbacken skal understøtte de studerendes faglige selvtillid, argumenterer Nicol og Macfarlane-Dick (2006) for 1) at adskille karaktergivning fra feedbacken og 2) at lægge vægt på, at feedback gives på produktet og ikke på producenten. Implementeringen af peer-feedback i Econometrics II fulgte begge disse anbefalinger, idet peerfeedbacken udelukkende bestod af anonyme, skriftlige kommentarer med fokus på, hvad der kunne forbedres i en konkret anonym opgave. At peer-feedback-processen bidrog til at opbygge større selvtillid i forhold til i hvert fald nogle studerendes forståelse af pensum, eksemplificerer følgende kommentar fra en studerende:

I became more confident about the theory and learned very much about structure and the most effective way to structure the assignments.

(Evaluering af peer-feedback, efterår 2018)

Sjette princip peger på, at god feedbackpraksis tilbyder mulighed for at lukke hullet mellem nuværende præstation og ønsket præstation. Portfolioeksamensformen, hvor de studerende skulle genaflevere de fleste af de opgaver, de havde fået peer-feedback på, til eksamen, gav som tidligere beskrevet stærke incitamenter til at bruge feedbacken til revision. Genaflevering er sidste kronologiske trin i feedback-loopet (Reinholz, 2016), men var fundamentet for hele fagets feedbackstruktur, og de studerende, der blev interviewet, nævnte "genaflevering" som en helt central grund til, at feedback kunne udfylde en særligt stor og lærerig rolle i faget.

Og der er det rigtig relevant at kunne gå tilbage til sin aflevering og lave den igen eller rette den til, så den bliver bedre, efter man har fået feedback fra andre elever og fra foreloeseren. Fordi vi skal op i de samme afleveringer, så giver det ikke mening ikke at skrive det ned, mens vi husker det. Så det er meget rart at mødes bagefter og få rettet opgaverne til. Og det er der sikkert nogle, der gør i andre fag, men det har jeg aldrig rigtig fået gjort. Jeg er sikker på, at det er super smart at gøre, men det er ikke lige blevet til noget.

(Citat fra interview, von Müllen et al. (2018), s. 66)

Det samme feedback-loop blev gentaget fem gange i løbet af semestret. Det gjorde de studerende mere trygge ved processen, og det bidrog også til, at de studerendes kunne opleve, hvordan de for hver gang kom nærmere deres faglige mål. Hvert semester oplevede både vi og de studerende selv en tydelig forbedring i kvaliteten af både afleveringerne og peerfeedbacken over semestret.

Det syvende princip tilsiger, at feedbackpraksis også skal sikre feedback til underviser, som denne kan bruge til at tilpasse og udvikle undervisningen, og som allerede beskrevet fik underviser information om kvaliteten af de studerendes afleveringer og kvaliteten af peerfeedbacken ved at læse stikprøver. Han så, når der var problemer med peer-feedbacken, ved at de studerende satte flag ved modtaget feedback, og han lod de studerende rate den modtagne feedback som en indikation af tilfredshed. Al den feedback blev brugt til at tilrettelægge både den kollektive feedback, der afrundede hver peer-feedback-cyklus, og til at justere de kommende cyklusser og undervisningens indhold $\mathrm{i}$ almindelighed.

Feedback i forberedelse og undervisning

For at klargøre den gode præstation, som er Nicol og Macfarlane-Dicks første princip, blev de underliggende pædagogiske principper og formålet med de forskellige aktiviteter tydeligt beskrevet og uddybet for de studerende fra start og gennem hele semestret. De interviewe- 
de studerende nævner som væsentlig for deres store læringsudbytte af faget, at der blev gjort virkelig meget ud af at eksplicitere klare krav og klart formål. Efter omstruktureringen arbejdede de studerende desuden med quizzer eller opgaver i alle dele af undervisningen, og der blev altid fulgt op med bud på gode svar enten i en gennemgang ved underviser eller $\mathrm{i}$ en skriftlig løsning, hvilket både gav de studerende eksempler på god praksis, jf. det første princip, og kvalitetsfeedback, jf. det tredje princip.

Implementeringen af et flipped classroom og omstruktureringen af øvelsestimerne, så de studerende selv arbejdede aktivt med at løse opgaver, fulgte Nicol og Macfarlane-Dicks andet princip, idet de studerende i hele undervisningsforløbet fik mulighed for at reflektere over og monitorere deres læring.

Inden forelæsningerne kunne de studerende ved hjælp af review-quizzerne på et relativt lavt taksonomisk niveau monitorere deres læring selvstændigt og asynkront, og muligheden for at stille spørgsmål faciliterede, at de selvevaluerede deres vidensbehov.

Aktiveringen i forelæsningerne og det selvstændige arbejde i øvelsestimerne gav de studerende det næste lag af muligheder for at selvevaluere og monitorere deres læring. I forelæsningerne fik de studerende eksempelvis information om deres læring på et højt taksonomisk niveau, idet quiz-spørgsmålene typisk testede deres evner til at overføre generelle principper til en ny kontekst. Derigennem blev det afsløret for de studerende, om de virkelig havde forstået de underliggende principper eller blot var i stand til eksempelvis at huske en specifik matematisk formel.

Det lykkedes med en gennemtænkt feedbackpraksis at skabe en udpræget dialogisk kultur i faget i overensstemmelse med det fjerde princip. I fagets online diskussionsforum foregik en omfattende og levende dialog mellem studerende og underviser baseret på de studerendes spørgsmål forud for forelæsningerne såvel som til opgaverne. I forelæsningerne og øvelsestimerne var der intern dialog mellem studerende, når de samarbejdede om at besvare quizzer og løse opgaver, mens der også foregik dialog med underviserne, der bevægede sig rundt til grupperne af studerende. Endelig var der efter forelæsningerne en $k ø$ af studerende, der stillede underviser spørgsmål til pensum og de obligatoriske opgaver.

En studerende beskriver dialogkulturen i faget således:

Morten is very successful in connecting and communicating with students both on Absalon and during the lectures. The way he includes the students creates a culture, where asking questions is "cool" and productive. In differ from other professors, Morten manages to a two-way communication. In other words, he is taking into account what the students find difficult by focusing on the most difficult factors.

(Slutevaluering, efterår 2018)

Vores oplevelse var, at den konstante aktivering af de studerende i og uden for undervisningen, kombineret med tilgængeligheden af online review-quizzer, videoer og tutorials, hjalp mange studerende til at opbygge selvtillid og en tro på, at de kunne opnå fagets læringsmål, sådan at undervisningen fulgte det femte princip. Eksempelvis blev quizspørgsmål, hvor mange studerende svarede forkert, fulgt grundigt op på og i den efterfølgende forelæsning repeteret med et twist, hvilket ledte til, at flere studerende svarede rigtigt og fik en oplevelse af, at "nu forstår jeg det". 
Med hensyn til det sjette princip havde de studerende adgang til mange ressourcer, der kunne hjælpe dem til at lukke hullet mellem nuværende og ønsket viden. Videoerne gjorde det muligt for studerende at gense undervisers gennemgang af fagstoffet, når det passede dem, og så mange gange som ønsket. Ved at stille spørgsmål inden forelæsningerne kunne de studerende direkte efterspørge en detaljeret gennemgang af det, de fandt svært at forstå. Endelig havde de efter aktiviteterne i undervisningen altid adgang til enten undervisers gennemgang (også i de annoterede slides), en skriftlig løsning på en opgave eller en online tutorial.

Endelig sikrede undervisningens struktur, at underviser hele tiden modtog feedback på de studerendes læring, der, som det syvende princip tilsiger, løbende blev anvendt til at tilpasse undervisningen. Inden forelæsningerne modtog underviser feedback fra besvarelserne af review-quizzerne og de studerendes spørgsmål, som blev brugt til at tilpasse undervisningen, så de studerendes spørgsmål blev besvaret, og quizspørgsmålene fokuserede på de dele af pensum, som de studerende havde svært ved. I forelæsningerne blev de studerendes svar på quizspørgsmålene brugt til at tilpasse detaljeringsgraden i den efterfølgende opfølgning og eventuelle repetitioner af svære spørgsmål. Endelig gav undervisers tilstedeværelse i de teoretiske øvelsestimer ham indsigt i, hvordan de studerende arbejdede med opgaverne, og hvilke dele de havde svært ved, hvilket ofte blev brugt til at tilpasse opfølgningen i den efterfølgende forelæsning.

\section{Opsummering af god feedbackpraksis}

Den nye opbygning af faget blev altså på baggrund af Nicol og MacFarlane-Dicks (2006) syv principper gennemsyret af feedback, som både flød mundtligt og dialogisk mellem selvvalgte par eller triader af studerende med tillid til hinanden; skriftligt og anonymt på tværs af alle studerende på holdet; fra underviser til studerende i kollektiv feedback, opsamling på quizzer og online diskussioner; og fra studerende til underviser som (stikprøver af) opgavebesvarelser og peer-feedback, som gradvist mere sofistikerede faglige spørgsmål og som svar i review-quizzer og student response systems.

\section{Resultater af fagets omstrukturering}

Vores vurdering er, at den feedback-fokuserede omstrukturering, som gradvist er tilrettet mellem 2016 og 2018, samlet set var en stor succes. Der er mange indikatorer, som illustrerer den begejstring, der har omgivet faget; f.eks. undervisningspriser til førsteforfatteren, og vi har efterfølgende set, at flere studerende lagde en større arbejdsindsats over hele semestret og opnåede et større selvrapporteret læringsudbytte og bedre karakterer, og at en større andel bestod eksamen.

Vi gør opmærksom på, at de beskrevne resultater og udvalgte citater naturligvis kun afspejler erfaringerne fra de studerende, der besvarede evalueringerne og deltog i interview, som beskrevet i Tabel 2 .

\section{Selvrapporteret tidsforbrug}

En væsentlig motivation for omstruktureringen af faget var ønsket om, at flere studerende arbejdede aktivt med faget over hele semestret. Fagets ECTS-normering betyder, at en gennemsnitlig studerende burde bruge ca. syv timer om ugen uden for undervisningstiden. Figur 2 viser, at de studerendes selvrapporterede ugentlige tidsforbrug uden for undervisningstiden steg efter omstruktureringen fra efteråret 2016. Andelen af studerende, der brugte un- 
der fire timer om ugen, faldt fra hhv. 31 og 42 procent i forår og efterår 2015 til maksimalt 16 procent efter 2016. Samtidig steg særligt andelen af studerende, der brugte mere end otte timer om ugen, fra 3-4 procent før 2016 til 24-32 procent efter 2016. I evalueringerne nævnte mange studerende desuden i kommentarerne, at de brugte mere tid på faget i løbet af semestret end $i$ andre fag.

Det er ikke i sig selv en god ting, at studerende bruger meget tid, hvis det høje tidsforbrug bare skyldes mange krav og obligatoriske elementer, som ikke fører til læringsmålene (Hattie, 2009). Vi har dog flere grunde til at tro, at det høje tidsforbrug i dette tilfælde var et godt tegn. Vi er bevidste om, at time on task er en væsentlig prædiktor for akademisk succes (Kuh et al., 2008). Vi opfatter de studerendes øgede tidsforbrug som en konsekvens af, at fagets mange selvreguleringsunderstøttende feedbackpraksisser gjorde det muligt for de studerende at se, hvordan de skulle bruge deres tid for at blive dygtige, og motiverede dem til- den ekstra indsats, som førte til ekstra læring, som vi beskriver nedenfor.

\section{De studerendes ugentlige tidsforbrug uden for undervisningstiden steg}

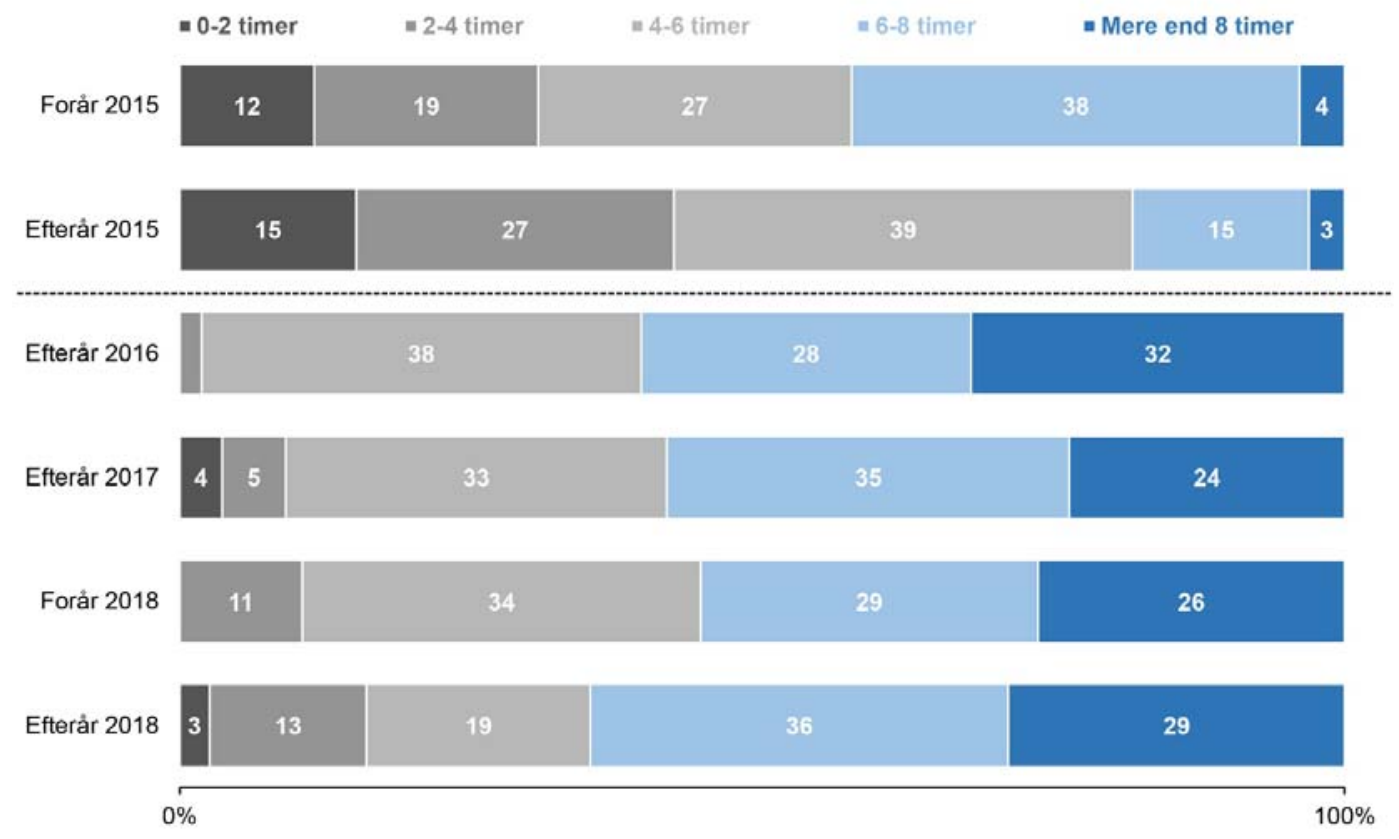

Figur 2. Figuren viser de studerendes ugentlige tidsforbrug på faget, som selvrapporteret i slutevalueringerne.

Vi kan også se, at de studerendes arbejdsindsats ikke hovedsageligt lå i eksamensperioden, men var fordelt over semestret, hvilket øger sandsynligheden for, at indsatsen resulterer $\mathrm{i}$ varig læring. Eksempelvis forberedte langt størstedelen af de studerende sig forud for undervisningen. Det bekræftes bl.a. i midtvejsevalueringen efterår 2018, hvor 90 procent af de studerende svarede, at de typisk forberedte sig til forelæsningerne. Til sammenligning svarede kun ca. halvdelen af de studerende i 2016, at de forberedte sig til forelæsningerne.

One of the things I value the most is that you have managed to make us work through the entire semester instead of the last weeks close to the exam. 
By reviewing other students' assignments you are almost forced to be engaged in the curriculum, and have to understand the subjects. Where in other classes $u$ can just cram for the exam two weeks before. Where as here you have to know what you are doing from the beginning of the semester.

(Slutevaluering, efterår 2018)

Endelig omtalte de fleste af de studerendes evalueringskommentarer om stort tidsforbrug den store arbejdsindsats positivt og knyttede den direkte til et stort oplevet læringsudbytte, hvilket følgende kommentarer eksemplificerer:

To get a good output of this course, I have spent on average a lot more time on reading, assignments and exercises compared to other courses. But the investment is well given.

The way the course is structured entails that you spend a lot of time on it, because this is the way you learn the most.

I have learned a lot about the econometrics since starting. Obviously you needed to study a lot as a student, to understand it, but generally I got a lot out of it.

(Slutevaluering, efterår 2018)

Det skal dog nævnes, at ikke alle har været lige begejstrede for de studerendes store (og udbytterige) tidsforbrug i Econometrics II. Fra studieadministrationen forlyder det, at den tid, de studerende brugte på faget, ikke gik fra deres fritid eller (omfattende) erhvervsarbejde, men fra andre fag, og det i en grad, så der var en overrepræsentation af studerende, der valgte et fag fra og altså kun fulgte 22,5 ECTS på det semester, hvor Econometrics II ligger. Det udgør naturligvis et økonomisk problem for uddannelsen. Men samlet set var der efter omstruktureringen stadig flere studerende, der brugte mindre end den forventede tid på faget, end der var studerende, der brugte mere end den forventede tid.

Selvoplevet loeringsudbytte

Et meget vigtigt resultat af fagets omstrukturering var, at de studerende oplevede et større samlet læringsudbytte.

I have never learned as much from a course as Econometrics II. While it was sometimes theory heavy, I have learned to apply the theory with a critical mindset and to write academically. The course structure facilitated the learning in an excellent way, and it was always clear what we were expected to do.

(Slutevaluering, efterår 2018)

Figur 3 viser en positiv tendens i de studerendes vurdering af deres samlede læringsudbytte, idet flere studerende i slutevalueringerne fra 2015 til 2018 angiver at have fået et stort eller meget stort læringsudbytte. Eksempelvis angav 83 procent at have fået et meget stort læringsudbytte i efteråret 2018 mod hhv. 50 og 30 procent i foråret og efteråret 2015. Samtidig faldt andelen, der angav at have opnået et gennemsnitligt læringsudbytte, fra hhv. 23 og 21 procent i foråret og efteråret 2015 til maksimalt fire procent efter omstruktureringen af faget introduceret i efteråret 2016, mens maksimalt to procent svarede, at de havde opnået et meget lille eller lille læringsudbytte efter omstruktureringen. 
Mere specifikt oplevede de studerende også at have fået et stort udbytte af peer-feedbackprocessen samlet set. I evalueringen af peer-feedback-processen foretaget i slutningen af efterårssemestret 2018 vurderede 75 procent af de studerende at have fået et stort eller meget stort læringsudbytte af peer-feedback-processen samlet set, se Figur 1 .

\section{De studerendes læringsudbytte steg}

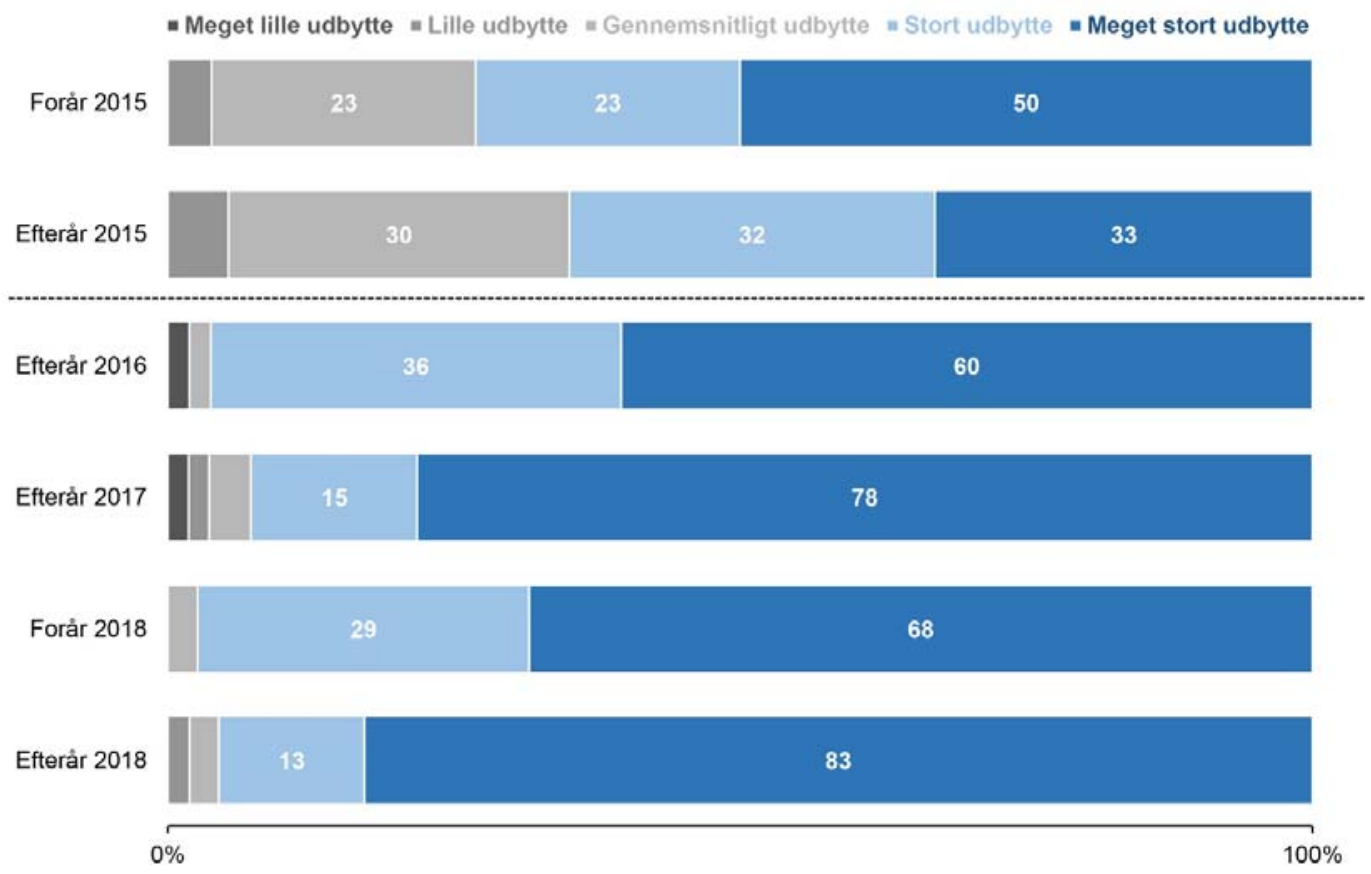

Figur 3. Figuren viser de studerendes selvrapporterede læringsudbytte fra fagets slutevalueringer i de enkelte semestre.

\section{Bedømmelse}

Det var ikke kun de studerende selv, der oplevede, at de blev dygtigere efter omstruktureringen af faget. De blev også bedømt bedre. Efter omstruktureringen så vi en markant stigning i karaktererne givet i faget, og vi så, at en større andel af de studerende, der var tilmeldt eksamen, bestod eksamen, som det kan ses i Figur 4.

Karaktererne afgivet ved den mundtlige eksamen før 2016 og ved portfolioeksamen efter efteråret 2016 kan naturligvis ikke direkte sammenlignes idet både eksamensform og bedømmelseskriterier er forskellige. Vi vurderer dog, at de studerende blev bedømt på et højere taksonomisk niveau ved portfolioeksamen, og at de højere karakterer og den større andel, der bestod faget, var udtryk for øgede realkompetencer. Artiklens førsteforfatter, som har været bedømmer på faget både før og efter omstruktureringen, er af den klare opfattelse, at de nye tiltag efter omstruktureringen hjalp til, at mange studerende opnåede en dybere forståelse af den statistiske teori og en generelt øget evne til kritisk tænkning. Derudover blev de studerende ved portfolioeksamen bedømt på en langt større del af pensum. 


\section{Karaktererne steg og flere bestod eksamen}

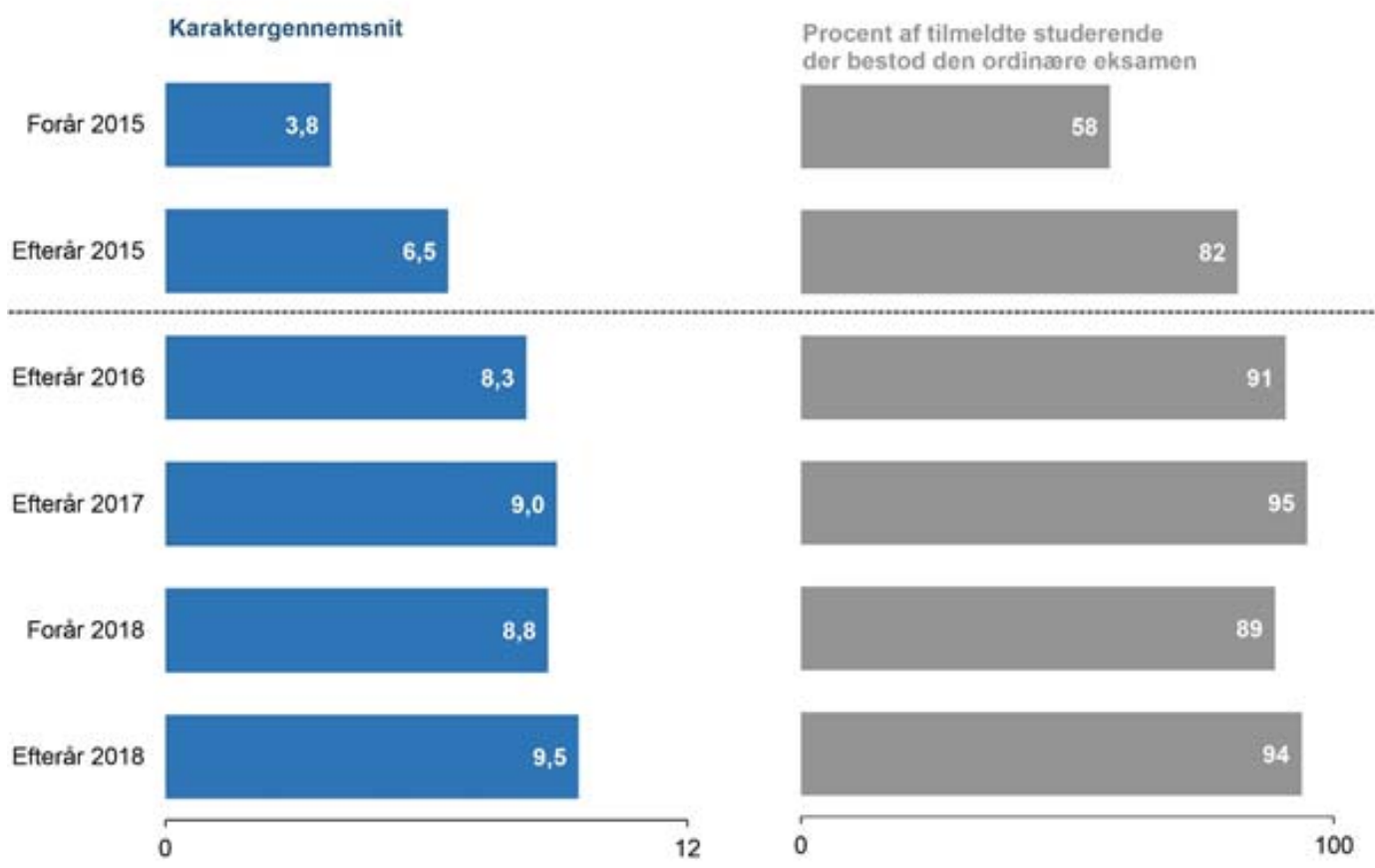

Figur 4. Figuren viser karaktergennemsnittet (til venstre) og procentdelen af de tilmeldte studerende, der bestod den ordinære eksamen (til højre).

Specifikt steg karaktergennemsnittet fra 4,6 og 6,3 i hhv. foråret og efteråret 2015 til mellem 8,3 og 9,5 i hhv. efteråret 2016 og 2018 (inkl. reeksamen). Samtidig steg procentdelen af de tilmeldte studerende, der bestod den ordinære eksamen, fra hhv. 63 og 73 procent i foråret og efteråret 2015 til et niveau på mellem 89 og 95 procent. Endelig faldt antallet af studerende, der var tilmeldt reeksamen, fra hhv. 34 og 43 i foråret og efteråret 2015 til mellem nul og tre efter omstruktureringen.

As previously stated, Econometrics II is the course where I have learned the most. This is both theory-wise, but also critical thinking and argumentation. Not many courses force you (and teach you) to apply your critical thinking and discuss the theory and material in a way that is done in Econometrics II. This results in a course that is both interesting, difficult but also very rewarding to follow.

(Slutevaluering, efterår 2018)

\section{Opsamling og anbefalinger}

Vi har beskrevet den omfattende multidimensionelle omstrukturering af faget Econometrics II fra 2015 til 2018. Vi har beskrevet motivation bag omstruktureringen, formålet, at undervisningen og eksamen i højere grad skulle alignes med læringsmålene for at motivere de studerende til at tillægge en dybdestrategisk læringstilgang, og vi har beskrevet hvordan den implementerede struktur fulgte Nicol og Macfarlane-Dicks (2006) syv principper for god feedbackpraksis, der fører til selvregulering. Endelig har vi påvist, at der efter omstruktureringen af faget sås et større selvrapporteret tidsforbrug og læringsudbytte kombineret med bedre karakterer og en højere beståelsesandel. 
Til slut vil vi tilføje endnu en vigtig faktor, man skal have for øje, hvis man vil bruge faget som model for fagudvikling andre steder; vi kalder det 'implementeringsomhu'. Alle pædagogiske praksisser er det, vi kan kalde implementeringsfølsomme. En af hovedkonklusionerne i Schneider \& Preckels (2017) metaanalyse af, hvad der virker i videregående uddannelsespraksis, er, at en undervisningsmetodes effektivitet afhænger af detaljerne i, hvordan den implementeres. Peer-feedback er en pædagogisk praksis, der i særdeleshed står og falder med organiseringen og logistikken (Topping, 2009; Panadero et al., 2016).

Så der kan være utallige forklaringer på, at gode intentioner og planer ikke kan omsættes i øjeblikkelig succes ved omstrukturering af undervisning.

Econometrics II-eksemplets succes har bund $\mathrm{i}$ en iterativ udviklingsproces over tre-fire år. Mange delinitiativer har ikke virket perfekt i første forsøg, men i stedet for at blive opgivet er de løbende blevet evalueret, diskuteret og forbedret. Denne implementeringsomhu og tålmodighed bør ikke undervurderes som forklaring på fagets succes.

Til andre, der måtte stå over for omstruktureringer af fag, der på en eller flere dimensioner ligner Econometrics II, vil vi anbefale:

- At kombinere peer-feedback med portfolioeksamen, så der er et direkte og tydeligt incitament til at give peer-feedback og revidere opgaverne.

- At strukturere undervisningen, så den fokuserer på aktiv læring og feedback begge veje.

- At evaluere løbende med fokus på studerendes læringsudbytte og på, hvordan læringsaktiviteterne kan forbedres.

- At gøre sig umage med detaljerne i implementeringen af den nye struktur.

God fornøjelse med undervisningen!

\section{Litteratur}

Bergmann, J., \& Sams, A. (2012). Flip Your Classroom: Reach Every Student in Every Class Every Day. Creative education, 7 (9), 120-190

Biggs, J., og Tang, C. (2011). Teaching for Quality Learning at University- What the Student Does. ( $4^{\text {th }}$ Ed.). UK: Open University Press.

Draper, S. W. (2009). What are learners actually regulating when given feedback?.British Journal of Educational Technology, 40, 306 - 315. doi:10.1111/j.1467-8535.2008.00930.x

Deiglmayr, A. (2018). Instructional scaffolds for learning from formative peer assessment: Effects of core task, peer feedback, and dialogue, p. 193. Eur J Psychol Educ, 33, 185. https://doi.org/10.1007/s10212-017-0355-8

Gibbs, G., \& Lucas, L. (1997). Coursework Assessment, Class Size and Student Performance: 1984-94, Journal of Further and Higher Education, 21:2, 183-192.

Doi:10.1080/0309877970210204

Gibbs, G. (1999). Using Assessment Strategically to Change the Way Students Learn. In 
Brown, S., Glasner, A., Assessment Matters in Higher Education (kap. 4). The Society for Research into Higher Education.

Hattie, J. (2009). Visible Learning: A synthesis of over 800 meta-analyses relating to achievement. New York: Routledge.

Hattie, J \& Timperley, H. 2007. "The power of feedback." Review of Educational Research 77.1: 81-112.

Kluger, A. N. \& DeNisi, A. (1996). The Effects of Feedback Interventions on Performance. Psychological Bulletin, 119(2), 254-284. doi: 10.1037/0033-2909.119.2.254.

Kuh, G. D. \& Cruce, T. M. \& Shoup, R. \& Kinzie, J. \& Gonyea, R. M. (2008). Unmasking the Effects of Student Engagement on First-Year College Grades and Persistence. The Journal of Higher Education, 79:5, 540-563. doi:10.1353/jhe.0.0019

Nicol, D., Macfarlane-Dick, D. (2006). Formative Assessment and Self-Regulated Learning: A Model and Seven Principles of Good Feedback Practice. Studies in Higher Education, 31:2, 199-218. doi: 10.1080/03075070600572090

Nicol, D., Thomson, A., Breslin, C. (2014). Rethinking Feedback Practices in Higher Education: A Peer Review Perspective. Assessment \& Evaluation in Higher Education, 39:1, 102-122. doi: http://dx.doi.org/10.1080/02602938.2013.795518

Panadero, E., Jonsson, A., Strijbos JW. (2016) Scaffolding Self-Regulated Learning Through Self-Assessment and Peer Assessment: Guidelines for Classroom Implementation. In Laveault D., Allal L. (eds). Assessment for Learning: Meeting the Challenge of Implementation. Springer International Publishing.

Ramsden, P. (2003). Learning to Teach in Higher Education (2 ${ }^{\text {nd }}$ ed.). Routledge.

Reinholz, D. L. (2016). The assessment cycle: a model for learning through peer assessment. Assessment \& Evaluation in Higher Education, 41:2, 301-315. https://doi.org/10.1080/02602938.2015.1008982

Richardson, J.T.E. (2015). Coursework versus examinations in end-of module assessment: a literature review. Assessment \& Evaluation in Higher Education, 40:3, 439-455. Doi: $10.1080 / 02602938.2014 .919628$

Rienecker, L., \& Jørgensen, P.S. (1999). Opgaveskrivning på videregående uddannelser (kap. 3). Samfundslitteratur

Schneider, M., \&Preckel, F. (2017). Variables associated with achievement in higher education: A systematic review of meta-analyses. Psychological Bulletin, 143:6, 565-600. http://dx.doi.org/10.1037/bul0000098

Topping, K.J. (2009). Peer Assessment. Theory Into Practice.48:1, 20-27. doi: $10.1080 / 00405840802577569$ 